\title{
Appraisement of Yield and Seed Production of Okra (Abelmoschus esculentus L. Moench) cv. Arka Anamika at Varying Sowing Dates
}

\author{
D. K. Upadhyay ${ }^{1}$, R. K. Singh ${ }^{2}$ and T. Chaubey ${ }^{2}$ \\ ${ }^{1}$ Department of Genetics and Plant Breeding, Rani Lakshmi Bai Central Agricultural \\ University, Jhansi-284003 (U.P.), India \\ ${ }^{2}$ ICAR-Indian Institute of Vegetable Research, Varanasi-221305 (U.P.), India
}

*Corresponding author

\begin{tabular}{|l|}
\hline Ke y w o r d s \\
Okra, Arka \\
Anamika, Fruit \\
yield, Seed yield, \\
Variety \\
\hline Article Info \\
$\begin{array}{l}\text { Accepted: } \\
\text { 05 April } 2020 \\
\text { Available Online: } \\
\text { 10 May } 2020\end{array}$ \\
\hline
\end{tabular}

\section{Introduction}

Okra (Abelmoschus esculentus L. Moench) is an important vegetable crop in tropical and subtropical parts of the world. It is a semiwoody, fibrous, herbaceous annual plant with an indeterminate growth habit (Balock, 1994). Existence of a large number of related species with wide variability and dominant characters suggest possible role of India as a secondary centre of origin (Gopalakrishnan and Peter, 2007). In India, it is grown for its tender green fruits during spring-summer with rainy season and it's used by people in different ways; immature pods are consumed as boiled vegetables; also dried and used as soup thickeners or in stews, which are rich sources of vitamins, calcium, potassium and other minerals. Okra is a nutritious vegetable which plays an important role to meet the 
demand of vegetables of the country when vegetables are scanty in the market.

The yield could reach as high as $30 \mathrm{t} / \mathrm{ha}$ (Koay and Chua, 1978). The unavailability of quality seed and heavy incidence of biotic stresses particularly yellow vein mosaic virus (YVMV) are the most important reasons for low yield. The disease YVMV transmitted by the whitefly (Bemisia tabaci) is reported to be one of the most destructive plant diseases in India causing great loss by affecting quality and yield of fruits, as high as $93.80 \%$ depending on age of plant at the time of infection (Sastry and Singh, 1974). Sowing time has a great impact on seed production and quality of okra (Singh et al., 1986; Hossain et al., 1999; Yadav and Dhankar 2001; Moniruzzaman et al., 2007). Besides, the time of seed sowing has a direct bearing on the incidence of YVMV disease in eastern India. Different environmental factors during seed production can influence seed yield and quality. It is very likely that with the increased critical approach to seed quality required for modern methods of vegetable production, we will have to make a greater distinction between seed quality and seed yield during the field multiplication of a cultivar. Adetunji and Chheda (1989) suggested that where limited resources prevent the use of several locations, different dates of planting for two or more years could be used to evaluate okra varieties for seed yield without losing much information on their relative ranking. Different cultivars require different climatic condition as well as different sowing time and a good cultivar sown at improper time to give poor yield.

In okra flower and bud drop before pod set are the major problems when the temperature is fluctuating and rises above $95^{\circ} \mathrm{F}$. Pollination is poor if temperature raises above $90^{\circ} \mathrm{F}$ and drop below $55^{\circ} \mathrm{F}$, also low intensity water stress and excess nitrogen inhibit pod formation. A previous report suggested that sowing date play an important role in growth and pod formation (Randhawe, 1967, Ali et al., 2019).

Both quantitative and qualitative traits of crops depend on sowing date and growing season. Determination of optimum sowing date is considered an important effort to have optimum yields. Okra sowing date as a factor affecting plant growth and yield depends on the prevailing environmental conditions especially temperature and relative humidity. Optimum temperature, low relative humidity and low rain fall during seed maturity resulted in higher yields of quality seed of cotton and some vegetables (Delouche, 1980), whereas, high temperature and humidity increased susceptibility of seed to fungal diseases. Okra requires warm to hot weather conditions $\left(23^{\circ} \mathrm{C}-37^{\circ} \mathrm{C}\right)$ for optimum growth and yield. Time to flowering and duration of growth strongly influences the climatic adaptation and yield potential of a crop. Variations in both relative humidity and temperature affected both okra growth and flower production (Dilruba et al., 2007, Sonu et al., 2013, Elhag and Ahmad, 2014). Keeping in view, the present experiment was conducted to find out the suitable sowing date to determine better yield and seed production of Okra.

\section{Materials and Methods}

The experiment was carried out at ICARIndian Institute of Vegetable Research, Varanasi (U.P.) during spring summer season from January to May 2015. The cultivar Arka Anamika of okra is sown in an area of 109.2 $\mathrm{m}^{2}$ and divided into 20 plots having the size of $1.8 \mathrm{~m} \times 1.25 \mathrm{~m}$ each and arranged in the four replications. The experiment was laid out in Randomized Block Design with 5 treatments. Before starting the experiment, the representative soil status were taken randomly 
at depth of $15 \mathrm{~cm}$ and analyzed for physical and chemical status. It was texturally classified as sandy loam soil and slightly alkaline in nature, has available $\mathrm{N}_{2} \quad 110.50$ $\mathrm{Kg} / \mathrm{ha}, \mathrm{P}_{2} \mathrm{O}_{5} 40.50 \mathrm{Kg} / \mathrm{ha}, \mathrm{K}_{2} \mathrm{O} 190.40 \mathrm{Kg} / \mathrm{ha}$, Organic carbon $0.12 \%$ with a $\mathrm{pH}$ of 8.6.

The experimental field was ploughed to make the soil fine tilth up to a depth of $15-20 \mathrm{~cm}$ with the help of disc plough and cultivator. According to plan of layout the field was prepared into different plots and made the ridges and irrigation channel between plots. During the land preparation the whole quantity of farmyard manure at the rate of twenty five tonnes per hectare was incorporated in the soil in addition to the recommended dose of half quantity of nitrogen $(60 \mathrm{~kg} / \mathrm{ha})$ and full dose of phosphorus $(50 \mathrm{Kg} / \mathrm{ha})$. The remaining doses of nitrogen was given into two split doses (30:30 kg/ha).

The zone is classified as one having a subtropical with two distinct seasons divided into Rainy (July-October) and summer (January-May). The treatments of summer season constituted five sowing dates in a sequential order at 10 day intervals, starting from 20th January (T1), 30th January (T2), 09th February (T3), 19th February (T4) and 01st March (T5). Hoeing and weeding were done to remove the weeds. Plant protection measures were used as and when required. Observations were made 30 days after sowing (DAS) at every 20 days interval and four plants were selected randomly from each plot except the border once to preventing border effect for study of plant height $(\mathrm{cm})$, number of leaves /plant, number of branches /plants, length of internodes $(\mathrm{cm})$, number of flowers/plant, number of days to first flowers, number of fruits/plant, length and diameter of fruit $(\mathrm{cm})$, weight of fruit $(\mathrm{g})$, number of seeds/pod, weight of 100 seeds (g) and seed index. The data were analyzed statistically by analysis of variance technique for RBD (Randomized Block Design) and the graph was prepared by using Microsoft excel.

\section{Results and Discussion}

The results of response of okra variety Arka Anamika to different sowing dates showed significant variations. Plant height was significantly affected by sowing dates, the maximum height of plant at 30 DAS, was recorded in the treatment T5 (1st March) with $13.87 \mathrm{~cm}, 50$ DAS with $22.99 \mathrm{~cm}$ and 70 DAS with $39.29 \mathrm{~cm}$, whereas in all subsequent days after sowing minimum height of plant were observed in $T_{1}$ (20th January) (fig.1). For the proper growth of plant legitimate environment like temperature, soil moisture and good air movement etc. are required. Similar were made by Elhag and Ahmed (2014), Ossom and Kunene (2011).

Number of branches / plant were measured at 40 and 60 DAS and the highest number of branches were noticed in T5 (2.75 and 4.25 respectively) (fig.3). Regarding maximum number of leaf / plant, it was observed as 12.06, 20.32 and 28.59 in the treatment T5 at 30, 50 and 70 DAS (fig.2). These results agree with the findings of Amjad et al., (2001). The maximum length of internode was observed at 60 days after sowing in the treatment $\mathrm{T}_{5}$ with $2.05 \mathrm{~cm}$ and minimum length of internode was found in the treatment T1 with $0.76 \mathrm{~cm}$, whereas similar finding was also examined after 40 days of sowing (fig.9). Regarding number of flowers after 50,60 and 70 DAS, the highest number of flowers were found at treatment T5 with 1.66, 4.77 and 5.78 respectively, whereas, it was again minimum in the okra plant sown at 20th January (fig.4). Regarding the number of fruits / plant, on 1st March sowing noticed maximum number of fruits 1.60, 4.56 and 5.59 at 50, 60 and 70 DAS while it was minimum in the treatment T1 (fig.5). It might 
be due to proper growth of plants under suitable favorable temperature, soil moisture and light intensity available in the month of March. The result was also supported by Hussain et al., (2006); Chattopadhyay et al., (2011); Das et al., (2012); Elhag and Ahmed (2014); Atallah (2016); Singh et al., (2018) and Ali et al., (2019).

The maximum length and diameter of fruits were recorded at maturity stage in the treatment T5 with $11.06 \mathrm{~cm}$ and $2.13 \mathrm{~cm}$ and minimum of $6.60 \mathrm{~cm}$ and 1.32 in T1 (fig.6). The number of seeds was affected by different sowing dates, the maximum number of seeds was obtained as 40.31 in the treatment $\mathrm{T} 5$, whereas minimum was found in the treatment T1 with 24.46. The maximum number of seed index was obtained in the treatment T5 5.62 $\mathrm{gm}$ and minimum number of seed index was found as $4.45 \mathrm{~g}$ in treatment T1 (fig.7). The observation regarding to first flower was observed in the treatment sown 1st March and 19th February and bear flower after 47.25 days after sowing and the farthest was noticed in the treatment T1 (52 days) (fig.8). The higher germination percentage and seed vigour index was recorded from 19th February and 1st March sowing because the matured pods faced less amount of rainfall during their harvesting period, resulting to more production of bold seeded pods at that time. However, rainfall at the time of seed maturity in delayed sowing is generally trapped in the area of embryonic axis, nodal zone and cotyledons of the seed. It was revealed that first flowering was not affected by different dates of sowing, there was no significant effect on days to first flowering, and this finding was also supported by Sharif et al., (2002); Moniruzzaman et al., (2007) and Dash et al., (2013).

Vigorous vegetative growth and high fruit set were noticed in March compare to February sowing. Plant height and number of leaves were significantly higher in March sowing compared to February sowing. Good vegetative growth and pod yield reflects high seed yield.

Table.1 Performance of different green fruit and seed yield contributing morphological characters of okra (Abelmoschus esculentus L. Moench) cv. Arka Anamika at varying sowing dates

\begin{tabular}{|c|c|c|c|c|c|c|c|c|c|c|c|}
\hline \multirow[t]{2}{*}{ Treatments } & \multicolumn{3}{|c|}{ Plant Height (cm) } & \multicolumn{3}{|c|}{ Number of Leaves } & \multicolumn{2}{|c|}{$\begin{array}{l}\text { Number of } \\
\text { Branches }\end{array}$} & \multicolumn{3}{|c|}{ Number of Flowers } \\
\hline & $\begin{array}{c}30 \\
\text { days }\end{array}$ & $\begin{array}{c}50 \\
\text { days }\end{array}$ & $\begin{array}{c}70 \\
\text { days }\end{array}$ & $\begin{array}{c}30 \\
\text { days }\end{array}$ & $\begin{array}{c}50 \\
\text { days }\end{array}$ & $\begin{array}{c}70 \\
\text { days }\end{array}$ & $\begin{array}{c}30 \\
\text { days }\end{array}$ & $\begin{array}{c}50 \\
\text { days }\end{array}$ & $\begin{array}{c}30 \\
\text { days }\end{array}$ & $\begin{array}{c}50 \\
\text { days }\end{array}$ & $\begin{array}{c}70 \\
\text { days }\end{array}$ \\
\hline $\begin{array}{l}\text { T1(20 January, } \\
\text { 2015) }\end{array}$ & 7.53 & 14.04 & 28.33 & 6.13 & 13.25 & 20.00 & 0.88 & 1.68 & 1.31 & 1.87 & 4.15 \\
\hline $\begin{array}{l}\text { T2 (30 January, } \\
\text { 2015) }\end{array}$ & 8.99 & 16.86 & 35.02 & 6.31 & 14.56 & 22.25 & 1.75 & 2.99 & 1.35 & 2.05 & 4.21 \\
\hline $\begin{array}{l}\text { T3 (09 } \\
\text { February, 2015) }\end{array}$ & 11.75 & 19.22 & 35.45 & 9.69 & 16.04 & 23.15 & 2.17 & 3.54 & 1.38 & 2.88 & 5.07 \\
\hline $\begin{array}{l}\text { T4 (19 } \\
\text { February, 2015) }\end{array}$ & 12.63 & 20.50 & 38.05 & 10.19 & 18.12 & 26.42 & 2.06 & 3.83 & 1.63 & 3.63 & 5.60 \\
\hline $\begin{array}{l}\text { T5 (01 March, } \\
\text { 2015) }\end{array}$ & 13.87 & 23.00 & 39.29 & 12.06 & 20.32 & 28.59 & 2.75 & 4.25 & 1.66 & 4.77 & 5.78 \\
\hline
\end{tabular}

Table.1 Cont. 


\begin{tabular}{|c|c|c|c|c|c|c|c|c|c|c|c|}
\hline \multirow[t]{2}{*}{ Treatmenwts } & \multicolumn{3}{|c|}{ Number of Fruits } & \multirow{2}{*}{$\begin{array}{c}\begin{array}{c}\text { Length } \\
\text { of Fruit } \\
\text { (cm) }\end{array} \\
60 \text { days }\end{array}$} & \multirow{2}{*}{$\begin{array}{c}\begin{array}{c}\text { Diameter } \\
\text { of Fruit }\end{array} \\
60 \text { days }\end{array}$} & \multirow{2}{*}{$\begin{array}{l}\begin{array}{l}\text { Weight } \\
\text { of } \\
\text { Fruit }\end{array} \\
60 \text { days }\end{array}$} & \multirow{2}{*}{$\begin{array}{c}\begin{array}{l}\text { Number } \\
\text { of seeds } \\
\text { per pod }\end{array} \\
90 \text { days }\end{array}$} & \multirow{2}{*}{$\begin{array}{c}\begin{array}{c}\text { Weight } \\
\text { of } \mathbf{1 0 0} \\
\text { seeds }\end{array} \\
90 \text { days }\end{array}$} & \multicolumn{2}{|c|}{$\begin{array}{l}\text { Length of } \\
\text { Internode }\end{array}$} & \multirow{2}{*}{$\begin{array}{c}\begin{array}{c}\text { Days to } \\
\text { First } \\
\text { Flowering }\end{array} \\
\text { No. of days }\end{array}$} \\
\hline & $\begin{array}{c}60 \\
\text { days }\end{array}$ & $\begin{array}{c}70 \\
\text { days }\end{array}$ & $\begin{array}{c}80 \\
\text { days }\end{array}$ & & & & & & $\begin{array}{c}40 \\
\text { days }\end{array}$ & $\begin{array}{c}60 \\
\text { days }\end{array}$ & \\
\hline $\begin{array}{l}\text { T1(20 } \\
\text { January, } \\
\text { 2015) }\end{array}$ & 1.18 & 1.58 & 3.85 & 6.60 & 1.33 & 13.50 & 24.47 & 4.45 & 0.55 & 0.76 & 52.00 \\
\hline $\begin{array}{l}\text { T2 (30 } \\
\text { January, } \\
\text { 2015) }\end{array}$ & 1.27 & 1.98 & 4.01 & 7.19 & 1.33 & 14.86 & 25.23 & 4.88 & 0.86 & 1.06 & 49.50 \\
\hline $\begin{array}{l}\text { T3 (09 } \\
\text { February, } \\
\text { 2015) }\end{array}$ & 1.30 & 2.35 & 4.98 & 7.82 & 1.53 & 15.47 & 26.69 & 4.90 & 1.02 & 1.35 & 47.75 \\
\hline $\begin{array}{l}\text { T4 (19 } \\
\text { February, } \\
\text { 2015) }\end{array}$ & 1.55 & 3.03 & 5.45 & 9.40 & 1.59 & 16.53 & 30.25 & 5.28 & 1.18 & 1.55 & 47.25 \\
\hline $\begin{array}{l}\text { T5 (01 } \\
\text { March, } \\
\text { 2015) }\end{array}$ & 1.60 & 4.56 & 5.59 & 11.06 & 2.14 & 17.57 & 40.31 & 5.63 & 1.30 & 2.05 & 47.25 \\
\hline
\end{tabular}

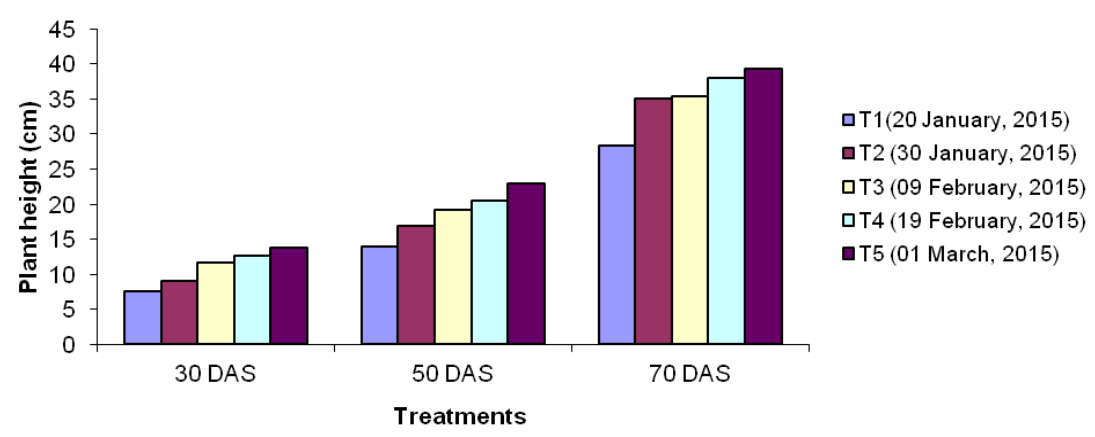

Figure.1 Plant height (cm) at 30,50 and 70 DAS affected by different dates of sowing

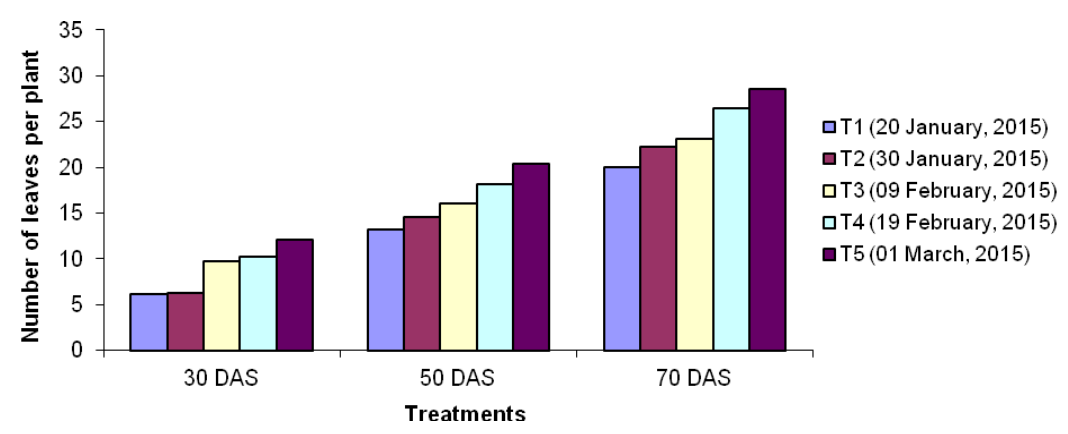

Figure.2 Number of leaves / plant at 30, 50 and70 DAS as affected by different dates of sowing 


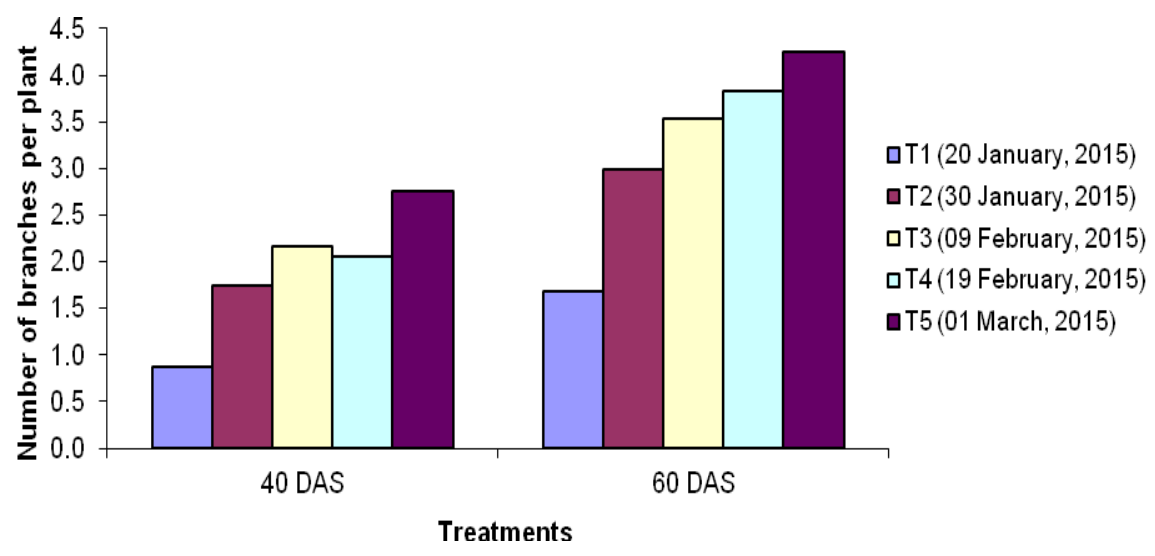

Figure.3 Number of branches / plant at 40 and 60 DAS as affected by different dates of sowing

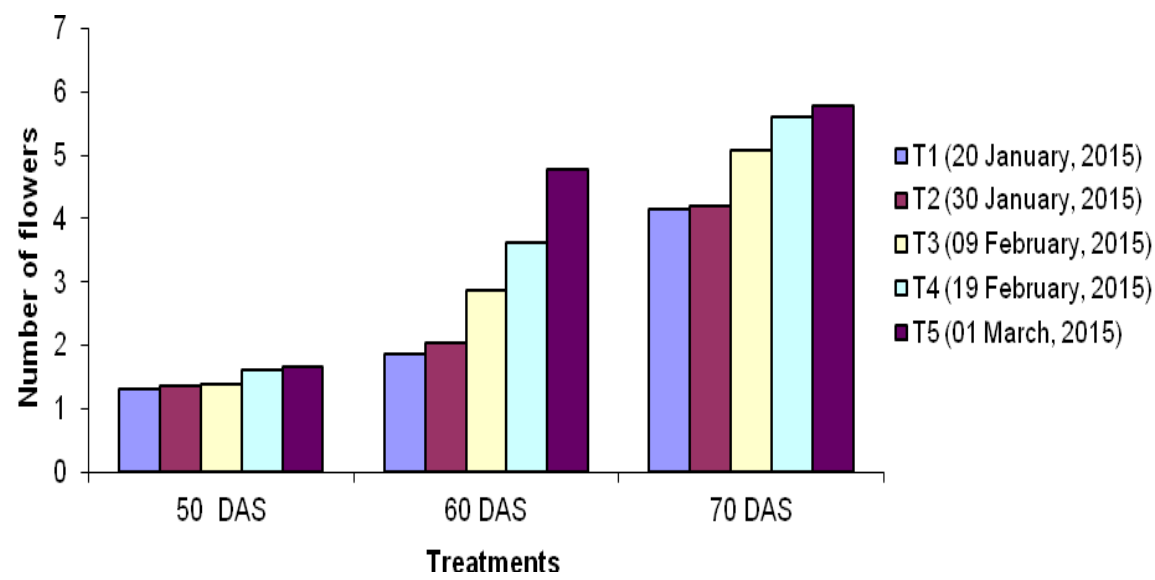

Figure.4 Number of flowers at 50, 60 and 70 DAS as affected by different dates of sowing



Figure.5 Number of fruits / plant at 60, 70 and 80 DAS as affected by different dates of sowing 


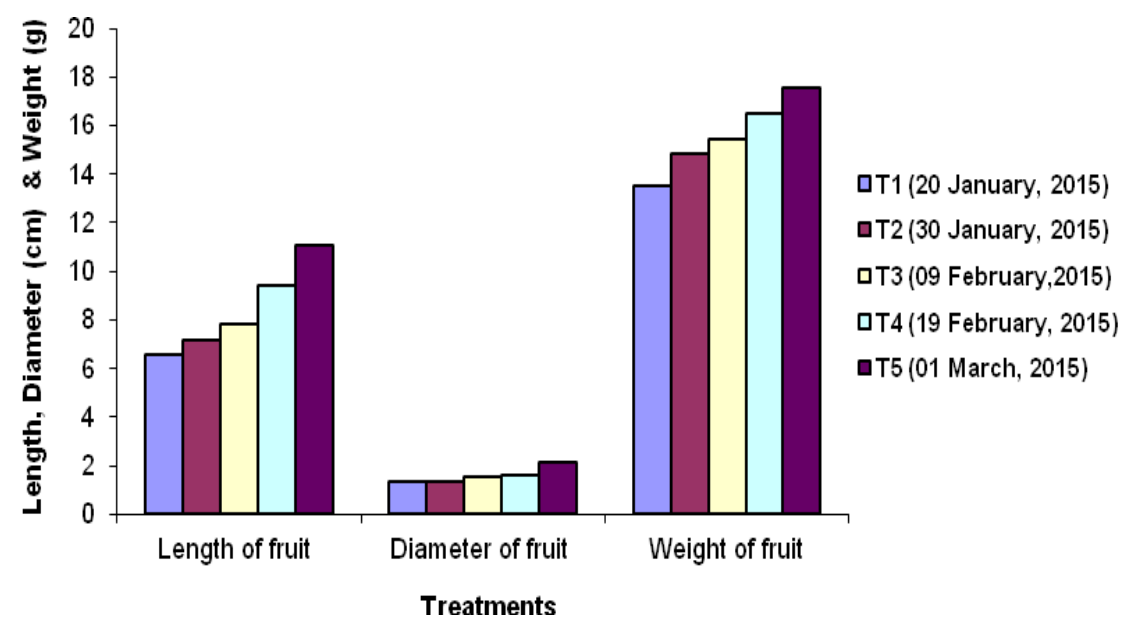

Figure.6 Length, diameter $(\mathrm{cm})$ and weight of fruits $(\mathrm{g})$ of fruit at maturity stage as affected by different dates of sowing

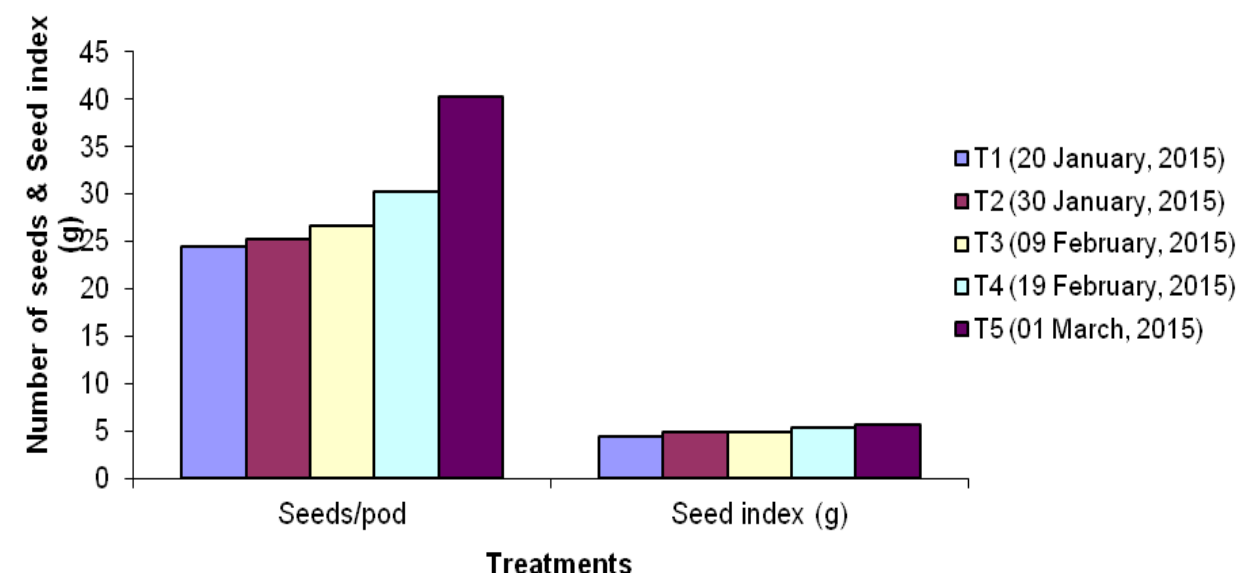

Figure.7 Number of seeds and seed index (g)
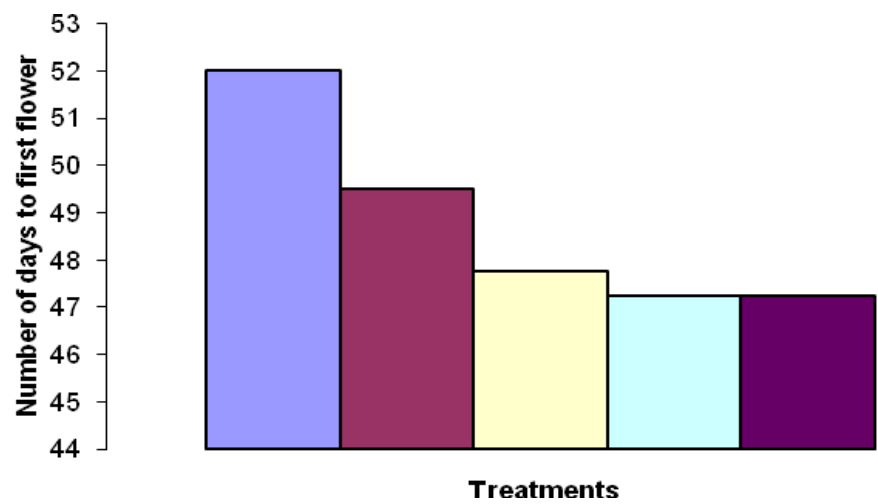

口T1 (20 January, 2015)

口T2 (30 January, 2015)

口T3 (09 February, 2015)

口T4 (19 February, 2015)

-T5 (01 March, 2015)

Figure.8 Number of days to first flower as affected by different dates of sowing 


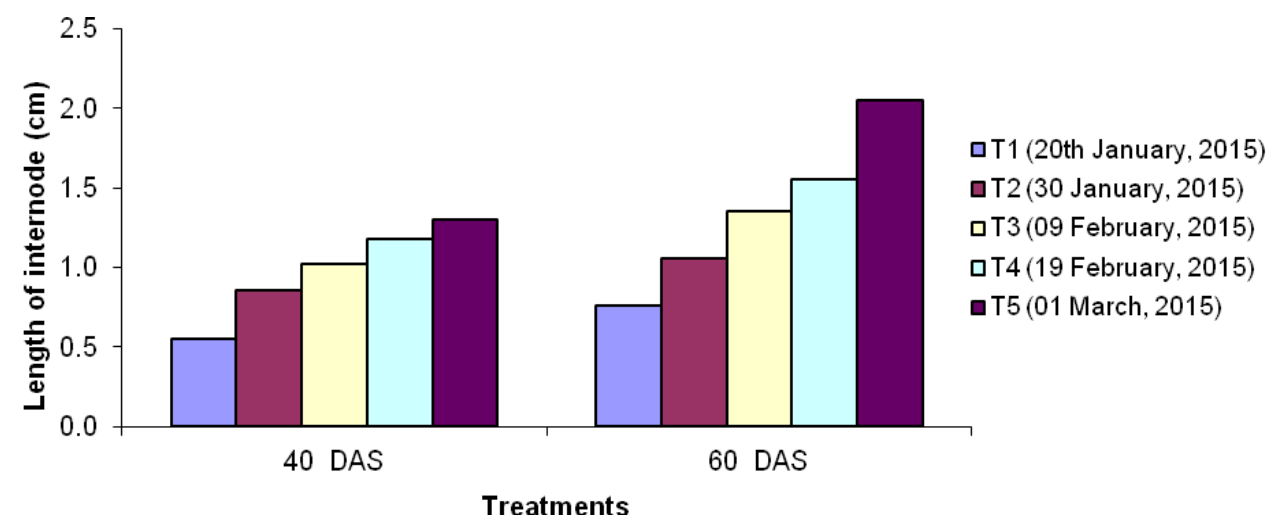

Figure.9 Length of internode $(\mathrm{cm})$ at 40 and 60 DAS as affected by different dates of sowing

From the results obtained, it can be concluded that the optimal sowing date for okra variety Arka Anamika would be first week of March. This is associated with a greater plant height (cm), number of leaves/plants, number of branches/plants, length of internode, number of flowers/plant, number of days to first flowers, number of fruits/plant, length and diameter of fruit, weight of fruit, number of seeds/pod, weight of 100 seeds and seed index.

\section{References}

Adetunji, I.A. and Chheda, H.R. (1989). Seed yield stability of okra as influenced by planting date. Plant Breed., 103, 212215.

Ali, Z., Imtiaz, M., Nabi, G., Ali, M. Y., Khan, M. A. and Jalal, F. (2019). Effect of sowing time and mulching type on growth, yield, and quality of Abelmoschus esculentus L. International Journal of Botany Studies, 4 (3), 166-170.

Amjad, M., Akam, M. and Hussain, S. (2001). Effect of different sowing dates and various doses of fertilizer on juveility and producutivity of okra. Pak. J. Agri. Sci., 38, 1-2.

Atallah, S.Y. (2016). Performance of Five Okra Cultivars Sown on Different Dates under Assiut Environmental Conditions. Assiut J. Agric. Sci., 47 (6-1), 217-224.

Balock, A.F. (1994). Vegetable crops: Horticulture. National Book Foundation, Islamabad. pp 529 - 531.

Chattopadhyay, A., Dutta, S. and Chatterjee, S. (1994). Seed yield and quality of okra as influenced by sowing dates. African J. of Biotec. 10 (28), 54615467.

Das, S., Chattopadhyay, A., Chattopadhyay, S.B., Dutta, S. and Hazra, P. (2013). Genetic parameters and path analysis of yield and its components in okra at different sowing dates in the Gangetic plains of eastern India. African Journal of Biotechnology, 11(95), 16132-16141 (2012).Dash, P.K., Rabbani, M.G. and Mondal, M. F.: Effect of variety and planting date on the growth and yield of okra. Int. J. Biosci. 3(9),. 123-131.

Dilruba, S., Hasanuzzaman, M., Karim, R. and Nahar, K. (2009). Yield Response of Okra to Different Sowing Time and Application of Growth Hormones. $J$ Hort. Sci. Orna. Plants, 1 (1), 10-14.

Dloueche, J. (1980). Environmental effects on seed development and quality. Journal of Horticultural Science. 15, 775-780.

Elhag, A.Z. and Ahmed, A.A. (2014). Effect of Cultivar and Sowing Date on Okra (Abelmoschus esculentus (L.) Moench.) 
Seed Yield. Universal Journal of Applied Science, 2(3), 64-67.

Gopalakrishanan, T.R. and Peter, K.V. (2007). Vegetables crops. New India publishing Agency, 4, 161.

Hossain, M.D., Salam, M.A., Islam, M.S. and Masud, M.A.T. (1999). Yield and quality of okra (BARI Dherosh-1) seed as influenced by time of sowing and plant spacing. Bangladesh J. Seed Sci. Technol., 3(1-2), 83-87.

Hussain, S., Sajid, M., Amin, A.S. and Iqbal, Z. (2006). Response of okra cultivars to different sowing times. J. Agri. Sci. 1 (1).

Koay, S.H. and Chua, S.E. (1978). Effect of fertilizers on vegetative growth and pod production in okra (Hibiscus esculentus L.). Singapore J. Prio. Ind., 6, 76-79.

Moniruzzaman, M., Uddin, M.Z. and Choudhury, A.K. (2007). Response of okra seed crop to sowing time and plant spacing in South Eastern hilly region of Bangladesh. Bangladesh J. Agril. Res., 32 (3), 393-402.

Ossom, E.M. and Kunene, V.N. (2011). Effect of planting date on seedling emergence and vigor of okra (Abelmoschus esculentus (L.) Moench.) World Journal of Agricultural Science, 7(3), 320-326.

Randhawe, G.S. (1967). Growth and development of okra (Abelmoschus esculentus (L.) Moench) as influenced by time of sowing and row spacing. $J$. of Res. P.A.U. Ludhiana, 4, 365-69.

Sastry, K.S.K. and Singh, S.J. (1974). Effect of yellow vein mosaic virus infection on growth and yield of okra crop. Indian Phytopath. 27, 294-297.

Sharif, H., Wahab, A.B. and Justur, M. (2003). Comparative studies on the effect of sowing date and spacing on the growth and yield of okra in different years. J. of Bio. Sci., 3 (12), 1173-1180.

Singh, H.M., Mishra, U.S. and Mishra, T.S. (2018). Effect of Sowing Time and Plant Spacing on Seed Production in Okra (Abelmoschus esculentus L.) in Madhya Pradesh. J Krishi Vigyan, 6 (2), 78-80.

Singh, K.P., Malik, Y.S., Lal, S. and Pandita, M.L. (1986). Effects of planting dates and spacing on seed production of okra (Abelmoschus esculentus (L). Moench. Haryana J. Hort. Sci., 15(3-4), 267-271.

Sonu, Singh, J.P., Rajbeer, N. and Kaushik, H. (2013). Effect of sowing dates and plant geometry on growth and yield of okra cv.Parbhani Krantiand Pusa A-4. The Asian J. Hort., 8 (2), 772-774.

Yadav, S.K. and Dhankar, B.S. (2001). Seed production and quality of okra (Abelmoschus esculentus (L.) Moench) as affected by sowing time and position of fruit on plant. Seed Res., 29(1), 4751.

\section{How to cite this article:}

Upadhyay, D. K., R. K. Singh and Chaubey, T. 2020. Appraisement of Yield and Seed Production of Okra (Abelmoschus esculentus L. Moench) cv. Arka Anamika at Varying Sowing Dates. Int.J.Curr.Microbiol.App.Sci. 9(05): 486-494. doi: https://doi.org/10.20546/ijcmas.2020.905.054 